\title{
A Meditação de Gonçalves Dias. A natureza dos males brasileiros ${ }^{1}$
}

\author{
DIEGO A. MOLINAI
}

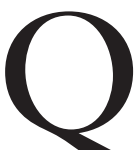

UANDO o jovem Gonçalves Dias, já consagrado poeta indianista, publica Meditação, obra fragmentária, escrita com uma prosa poética em tom de denúncia, não é possível traçar automaticamente uma linha contígua entre suas leituras (muitas depreendidas de suas traduções) e seu estilo. Nem posicionar o poeta maranhense na arena política, carregada de rispidez, entre o interregno, a "maioridade" e o os primeiros anos de D. Pedro II como imperador. Dessa forma, para abordar uma obra tão rica quanto desatendida por boa parte da crítica especializada, é necessário apresentar minimamente o contexto no qual se inscreve a Meditação, sem esgotar as múltiplas leituras, mas evidenciando as contradições intrínsecas de um processo em cujo seio se encontra nada menos que a emergência da modernidade e das perguntas pela questão nacional.

Como agentes diretos da formulação e configuração da chamada invenção do Estado nacional brasileiro, alguns dos escritores que figuravam nas listas das elites letradas reunidas em torno do Instituto Histórico e Geográfico Brasileiro (IHGB), encabeçado pelo imperador e mecenas D. Pedro II, enfrentaram uma ambiguidade de maneira particular. Enquanto tentavam dar forma ao imaginário social, sobretudo nos motivos indianistas, ousavam buscar um lugar de autonomia intelectual, isto é, fora do poder centralizador, a partir do qual realizar suas críticas. Tarefa arriscada e, presumivelmente, ingrata. Pois resulta perigoso criticar aquilo a que se intenta dar forma; ou melhor, criticar a maneira em que está se realizando aquilo sobre o que se tem ideias pouco precisas de como deveria levar-se adiante. Ou, talvez, simplesmente tarefa romântica, pois alberga a contradição no seu próprio seio. Dialética da ambiguidade a chamou José $\mathrm{Mu}$ rilo de Carvalho (2008, p.229-36).

Escrito originalmente após Gonçalves Dias regressar da Europa, o fragmento de prosa poética Meditação está dividido em três capítulos e datado em dois lugares. Os capítulos I e II estão datados em Caxias, nos dias 23 de junho de 1845 e julho de 1845, respectivamente. O capítulo III encerra-se com a seguinte indicação: “Maranhão, 8 de maio de 1846”, 2 escrito em São Luís. Além dos modelos adjudicados à Meditação, entre os quais se destacam Lamennais e Friedrich Schlegel, este último pelos seus Fragmentos, o certo é que prevalece a estrutura bíblica de versículos e não apenas na forma, mas na quantidade de imagens e no vocabulário utilizado; sem mencionar as constantes referências diretas, como o Livro de Jó. Alguns críticos têm indicado, também, alguma ana- 
logia com os diálogos platônicos que, acreditamos, resulta um pouco forçada. Em primeiro lugar, os diálogos platônicos têm um movimento, uma dinâmica, pois na Antiguidade andar e filosofar eram quase sinônimos. E na Meditação o único movimento é o das imagens. Em segundo lugar, a profusão de personagens, além das figuras centrais de alguns dos diálogos (como o Fédon), é enorme em Platão e na Meditação se limita à dupla jovem-velho, e a umas poucas vozes finais de sábios anciãos que vêm amenizar a narratio, mas não formar um consenso. Por último, os diálogos platônicos costumam esmiuçar algum assunto, a partir de diversos enfoques, e tudo gira em torno dessa ideia central (como o amor em $O$ banquete); já na Meditação a profusão é mais de temas que de personagens, e apesar de aparecer constantemente, como pano de fundo, a história do Império brasileiro e a emergência do Estado nacional, o contraponto de vozes do jovem e o velho discrepa sobre diversos temas: a escravidão, a desigualdade, a erudição, o ensino, a história, a meditação, a nacionalidade, o progresso, a natureza, o pensamento etc.

O texto teve de esperar alguns anos para ser publicado, até sua inclusão em O Guanabara. Revista mensal, artística, científica e literária, cujo primeiro número é de dezembro de 1849; publicação dirigida pelo próprio Gonçalves Dias, Araújo Porto-Alegre e Joaquim Manuel de Macedo. Antes, contudo, Gonçalves Dias chegou a enviar os dois primeiros capítulos a seu amigo Teófilo Leal do Rio de Janeiro, junto com uma carta na qual afirmava: "No vapor que daqui partiu antes deste, te remeti o $2^{\circ}$ capítulo da minha 'Meditação' - eu te irei mandando os outros capítulos; cortem sem dó - o que julgarem mau - ou arriscado de se imprimir" (Gonçalves Dias, 1964, p.69). Ou seja, o autor da Meditação já sabia o "arriscado" que poderia ser a publicação do fragmento, pelas críticas, por momentos ferozes, ao sistema escravista que contaminava a sociedade brasileira como um todo. E, contudo, três anos depois, quando Gonçalves Dias já tinha obtido dois cargos públicos, como professor do Liceu Niterói (agosto de 1847) e como membro do IHGB (outubro de 1847), e seu nome como poeta brasileiro e original tinha ganhado certo prestígio, após a boa acolhida europeia dos Primeiros cantos, com prefácio elogioso de Herculano, ele publica a Meditação numa revista financiada por D. Pedro II, nos cinco primeiros números de $O$ Guanabara. Ainda engrenado no aparato burocrático imperial, como funcionário e membro do IHGB, decide publicar o texto.

Como quase todas as revistas literárias, de ciência, de "modas", de artes etc., que desde a implementação da Imprensa Régia, por decreto de D. João VI em 1808, vinham praticando a tão prezada liberdade de expressão, $O$ Guanabara era um jornal que pretendia cativar um público leitor amplo. Nesse esforço ciclópico, pois o número real de leitores era ínfimo, O Guanabara se somava à empreitada de suas antecessoras, as revistas românticas mais destacadas da época, como a pioneira Nitheroy, publicada em Paris em 1836 - que na historiografia literária brasileira é marco consensual do início do romantismo no Brasil, junto 
com a publicação dos Suspiros poéticos e Saudades de Gonçalves Magalhães - e a Minerva Brasiliense (1843-1845).

Desde um centro que não o circunda, Gonçalves Dias publica sua Medita$c ̧ \tilde{a} o$, sem círculos que o assediem, em perfeita geometria com seus deveres críticos: "Demais não sou cortesão, não o quero ser, não o pretendo ser; não queria sobretudo aparecer ao público diverso do que sou" (Gonçalves Dias, 1964, p.108). A Meditação é uma radiografia que detecta o mal de que padece a jovem nação brasileira: o vínculo colonial com Portugal, ainda em vigor, a escravidão, a (suposta) indolência indígena, o laço ou as correntes nunca cortadas com o passado...

O texto começa com umas linhas de pontos de reticência na primeira parte do capítulo I, e continua com um "Então" na segunda parte. Isto é, a primeira palavra que lemos é esse "Então", o que nos permite arguir que Gonçalves Dias dá por pressuposto o começo, o porquê da Meditação. Deixemos de lado a possibilidade de censura (por parte de Teófilo Leal ou própria: “cortem sem dó"), já que pela prossecução semântica nada de censurável pode haver antes desse "Então". Então: a fragmentação da obra, não apenas na publicação do Guanabara, mas na sua totalidade; os pequenos trechos que prefiguram a própria fragmentação suscitada pela modernidade abrem com uma linha de pontos, colocando o relato espaço-temporalmente numa continuidade cuja origem é anterior, e que o leitor facilmente reconhece ao ler os fragmentos. Trata-se da História do Brasil, seu passado, o presente elástico da epifania-de-olhos-fechados e uma série de proféticas visões sobre um futuro nada alentador; tudo no marco maior que poderíamos chamar, sem estridências na época, de História da civilização. Trata-se, então, de entrever as glórias, mas também os perigos que ameaçam a Nação. Essa amplitude, que se desenvolve com os toques do velho nas pálpebras do jovem, também pode funcionar como "fator de indeterminação espaço-temporal da narrativa $[. .$.$] metaforizando cartograficamente a totalidade$ nacional" (Alves Cunha, 2001, p.XXXII).

A meditação do narrador-jovem começa quando o ancião lhe impõe as mãos nas pálpebras, dando início ao jogo de contrastes e oposições constantes apresentados ao longo do texto. A visão começa justamente quando o jovem fecha os olhos; logo, toda vez que o narrador volta à vertigem de seu corpo extático, ao abrir os olhos, só há brumas e desfalece. O poder da meditação terá elementos da epifania e da revelação, porém, apesar de que o ancião está sempre rodeado por uma luz tênue, um fogo primordial similar ao das aparições divinas do Antigo Testamento, o narrador não pode experimentar a onisciência e deve sucumbir a suas limitações, embora consiga levantar a voz para emular não apenas o que vê, mas também, e principalmente, como o vê. A onisciência, de todo modo, seria a impossibilidade de narrar, pois a eternidade e a ubiquidade pressupõem a simultaneidade (carecem de continuidade), portanto são inenarráveis. A experiência da meditação também é fragmentária, não é possível aprender a totalidade, ainda menos apreendê-la. 
A visão abre com o espetáculo natural de árvores robustas e frondosas "como se desde a criação presenciassem o incessante volver dos séculos" (Gonçalves Dias, s. d., p.5). ${ }^{3} \mathrm{~A}$ historização da natureza chega ao ápice, pois ela estaria ali desde a criação (desde sempre!), trata-se, como aclara o jovem, de uma "terra bendita". Porém, imediatamente, lemos uma oração adversativa sem advérbio, construída semanticamente. Pois nessa terra de natureza esplêndida e magnífica, nessa terra bendita, instala-se a diferença entre os homens. Depois da natureza aparece, pois, a primeira - e talvez mais vigorosa e efetiva - crítica ao sistema escravista; é uma imagem que se articula a partir do poder da multiplicação:

Vejo milhares de homens - de fisionomias discordes, de cor vária, e de caracteres diferentes. / E esses homens formam círculos concêntricos, como os que a pedra produz caindo no meio das águas plácidas de um lago. /E os que formam os círculos externos têm maneiras submissas e respeitosas, são de cor preta; e os outros são como um punhado de homens formando o centro de todos os círculos, têm maneiras senhoris e arrogantes; - são de cor branca. (ibidem, p.5-6)

Mas, além de realizar uma crítica à hierarquia a partir da imagem violenta da pedra na água, como se tudo começasse a se agitar de repente, Gonçalves Dias sugere uma advertência. Essa dupla leitura é interessante e condiz com o resto do texto que oscila constantemente, como mencionamos, entre dois polos opostos. A ambiguidade parece ser a forma escolhida por Gonçalves Dias para abordar criticamente a realidade que percebe, mas se no seu indianismo há uma separação entre o poético (índio ideal) e o etnográfico (índio real), na Meditação, talvez pela própria forma de atravessar as fronteiras dos gêneros ou pelo tom ensaístico, a duplicidade convive sem estremecimentos. Porque a metáfora dos círculos pode ser uma denúncia da desigualdade social, da desagregação, da hostilização e da submissão do homem pelo homem, sem dúvida, mas também pode representar um perigo ao configurar uma forma de assédio dos que estão nos círculos externos aos que se reúnem no centro, isto é, a elite branca (econômica) está rodeada. É uma espécie de república platônica simplificada, e o narrador parece estar do lado de fora, contando os sucessos, fora do nec otium; um poeta autoexpulso. Está claro que o público leitor de $O$ Guanabara podia entrever ali uma ameaça porque apesar das "maneiras submissas" dos negros há uma supremacia física, inclusive nos mais velhos, e um grito no sangue; enfim, há uma rebelião em potência.

A terceira parte do primeiro capítulo abre-se com uma cena humilhante, é $\mathrm{o}$ ato do açoitamento, o vexame, a punição que um "mancebo imberbe" pratica contra "outro de cor preta". A imagem é a mais violenta do texto. E no fim do suplício, segue-se esta descrição: "E o ofendido, velho e curvado sob o peso dos anos, cruzou os braços musculosos, apesar da velhice, e deixou pender a cabeça no peito" (Gonçalves Dias, s. d., p.7). Há uma força física que permanece dominada, a puro golpe de chicote, mas as correntes que mantêm os negros sujeitos à sua condição de vassalos produzem "o rugido de uma pantera". Essa ameaça não é casual. Porque por esses anos as rebeliões eram constantes, não 
só de negros, mestiços ou índios, também de elites locais de algumas províncias que numa onda de levantes assolaram o território imperial desde a década de 1830. Vale lembrar aqui a rebelião conhecida como Guerra dos Farrapos (18351845), com intenções separatistas, no atual território do Rio Grande do Sul; os focos rebeldes convergentes em Maranhão, um de vaqueiros e outro de negros fugitivos ao mando de Cosme, na chamada Balaiada (1838-1841); as rebeliões liberais e populares de 1842 em São Paulo e Minas Gerais etc. Nesse contexto, o perigo é iminente, visível. Além disso, a entrada (estimativa) de escravos por esses anos tem um pico alarmante, como se vê no Quadro $1 .{ }^{4}$

Quadro 1 - Estimativa de ingresso de escravos no Brasil

\begin{tabular}{|c|c|}
\hline Ano & Estimativa \\
\hline 1840 & 20.796 \\
\hline 1841 & 13.804 \\
\hline 1842 & 17.435 \\
\hline 1843 & 19.095 \\
\hline 1844 & 22.849 \\
\hline 1845 & 19.453 \\
\hline 1846 & 50.324 \\
\hline 1847 & 56.172 \\
\hline
\end{tabular}

Talvez haja ali uma explicação mais significativa da razão pela qual não houve censura imediata; já que entre as linhas de uma crítica se entrelaça uma advertência, a evidência de uma ameaça. De todo modo, o texto continua em forma de presságio: "E vi que o ferro resistia às suas tentativas; mas também vi que a sua raiva era frenética, e que o sangue que lhes manava das feridas cerceava o ferro como o enxofre incendido" (Gonçalves Dias, s. d., p.8). Isto é, a liberdade está no sangue, a natureza humana tende a essa liberdade, e se o rugido da pantera animaliza os escravos, a ação do enxofre incandescente os libera das correntes opressoras.

$\mathrm{Na}$ IV parte começa a ser delineada com maior detalhe o que se poderia chamar de visão negativa do império. Essas "verdades" que Gonçalves Dias coloca dentro de um processo histórico na visão panorâmica configuram um percurso que se assemelha, apenas no recurso, ao flashback de $A$ Confederação dos Tamoios de Gonçalves de Magalhães. Mas, diferentemente do romântico arre- 
pendido Magalhães, na Meditação essa visão panorâmica que abarca a totalidade da óptica da revelação tende a historicizar tudo. Isso está em comunhão com as poesias indianistas de Gonçalves Dias, nas quais: a conquista e o horror que suscitou, a escravidão indígena, a debilidade institucional e a violência dos portugueses devem ser parte integral do passado histórico da Nação, mas também, agora visto da Meditação, as raças que compartilham o solo (a "terra bendita", que também é nomeada como "terra da liberdade"), a escravidão negra, a desigualdade, a mestiçagem. O panorama não pode ignorar nenhum locus. Nisso Gonçalves Dias é o oposto de Gonçalves de Magalhães, mas também de Varnhagen, que praticam elisões, recortes e anulações de toda e qualquer importância de outros sujeitos históricos.

Embora com vaivéns argumentativos, Gonçalves Dias busca, sobretudo, uma autonomia, um lugar a partir do qual poder dizer a Nação. Essa autonomia está marcada pela crítica e, ao mesmo tempo, pelo comedimento para realizá-la. Pois o negativo se evidencia com maior clareza nos meios de produção atrasados e na "falta de instrução", crítica que estará balanceada e contraposta, como quase tudo na Meditação, pelos elogios e as saudações ao grande povo nascente. Contudo, é nesta IV parte que a visão se torna unívoca, porque o jovem narrador só enxerga um espetáculo horrendo diante de si: "vi somente - escravos [...] e por toda a parte - escravos!" (Gonçalves Dias, s. d., p.10). Embora a visão se torne unívoca não deixa de suscitar, uma vez mais, a dualidade. Isso porque em nenhum momento é possível identificar o que causa no narrador o espetáculo da escravatura, se repulsão ou vergonha. Primeiro, há uma menção ao juízo que os viajantes estrangeiros tinham ao chegar ao Brasil e ver tantos negros: "porque julga [o estrangeiro] que um vento inimigo o levou às costas d'África", dali a vergonha. Contudo, depois de notar que o estrangeiro descobre que está "no Brasil, na terra da liberdade", irrompe um parágrafo inteiramente construído por adversativas: "Mas grande parte de sua população é escrava - mas a sua riqueza consiste nos escravos - mas o sorriso - o deleite do seu comerciante - do seu agrícola - e o alimento de todos os seus habitantes é comprado à custa do sangue do escravo!" (ibidem, p.10, grifos nossos). Esses "mas" vêm embaçar a visão anterior que declarava o Brasil como "Terra da liberdade", colocando a escravidão como impedimento de tal rótulo. E no mesmo fragmento se cristaliza a crítica ao modo de produção, pois o comércio e a economia toda parecem estar sujeitos a esse sistema colonial e atrasado, e todo rédito vem "à custa do sangue escravo". Agora, para compreender melhor a ambivalência entre vergonha e repulsão da crítica de Gonçalves Dias, seria de grande utilidade reproduzir alguns dos inúmeros relatos de viajantes estrangeiros que chegaram às costas do Rio de Janeiro ou Bahia, principalmente na primeira metade do século XIX, e deixaram suas impressões sobre o quotidiano brasileiro. Essas narrativas de viagens eram leituras assíduas dos românticos. A modo de exemplo, bastem duas citações, a primeira de um escritor argentino, Domingo Faustino Sarmiento, que passou 
pelo Rio de Janeiro em 1846 (data muito próxima da escrita da Meditação), e a segunda dos conhecidos Spix \& Martius, cujos textos eram reproduzidos na Revista do IHGB.

Escreve Sarmiento (1949, p.50):

Incorpórome pesadamente, y los ruidos toman la forma neta y despejada de la realidad; asómome a la ventana que domina la plaza y la esclavatura se me presenta en toda su deformidad. Larga recua de negros encorvados bajo el peso de la carga seguian al trote al madrin que en la delantera agitaba sonajas y cascabeles y campanillas. Negros arrieros cerraban la procesión, chasqueando sus látigos sonoros para avivar el paso de las mulas humanas; y aquella bestia en dos pies, lejos de gemir bajo el peso, canta para animarse con el compás de su voz.

De repente, o pesadelo é real, chama-se escravidão, e essa aparece emoldurada "em toda sua deformidade" ao viajante. Vale enfatizar que esse é o mesmo Rio de Janeiro que conheceu Gonçalves Dias por esses meses, no mesmo ano de 1846. A crítica de Sarmiento é idêntica à de Gonçalves Dias: "A escravatura é como as fraldas da indústria", escreve linhas depois; o modo de produção no alvo, novamente, ou em chave romântica, o impedimento do progresso, que será tratado no final da Meditação.

Escrevem Spix \& Martius (s. d., p.46):

Língua, costumes, arquitetura e afluxo dos produtos da indústria de todas as partes do mundo dão à praça do Rio de Janeiro feição europeia. O que, entretanto, logo lembra ao viajante que ele se acha numa parte estranha do mundo, é sobretudo a turba variegada de negros e mulatos, a classe operária com que ele topa por toda parte, assim que põe o pé em terra. Esse aspecto foi-nos mais de espanto do que de agrado. A natureza inferior, bruta, desses homens insistentes, meio nus, fere a sensibilidade do europeu, que acaba de deixar os costumes delicados e as fórmulas obsequiosas das suas pátrias.

Os temores dos naturalistas europeus parecem calcados por Gonçalves Dias, numa inversão notável, desde já. O que fere a escravatura não passa pelo físico em Spix \& Martius, mas pelo ético e, em última análise, pelo estético: a insistência de homens seminus produz espanto e fere a sensibilité do europeu, de costumes delicados.

Imediatamente depois, a visão do jovem continua apontando a escravatura como a raiz de todos os males, e embora os exemplos de civilizações que levantaram grandes monumentos perduráveis não sejam dos mais felizes, ${ }^{5}$ a meditação chega até um ponto crucial, que é o anúncio de um Brasil que está por nascer, que ainda está em formato embrionário, apesar dos juízos do jovem. $\mathrm{O}$ ancião é quem o anuncia do seguinte modo: a sociedade brasileira é "um feto gigante que começa a desenvolver-se debaixo da influência poderosa do sol dos trópicos" (Gonçalves Dias, s. d., p.15). Com essa imagem estranha, Gonçalves Dias introduz a ideia herderiana da Nação como ser vivo. E, nesse caso, não se trata de um Brasil jovem, mas de um Brasil por nascer. Nesse caminho em direção do progresso há um sacrifício a ser realizado, um sacrifício para atingir 
o destino manifesto da nação embrionária. Para tal, o ancião "que tudo sabia" vale-se da figura bíblica de Isaac, o filho de Abraão a ser imolado. Eis o destino do Império, um destino bíblico. Não é do sacrifício indígena, como entreviu Alencar, mas do negro escravo que a nação se ergue, e de forma nada ideal.

E se restam dúvidas do destino da nação emergente, o capítulo II abre com uma epígrafe do Livro de Jó, citado na versão vulgata por Gonçalves Dias: “Vir vanus in superbiam erigitur, et tamquam pullum onagri, se liberum natum putat”' (embora Gonçalves Dias não coloque a referência, trata-se de Jó 11:12). As traduções abundam, os sentidos se multiplicam e o logos divino perde todo o privilégio da univocidade, mas numa das versões em português podemos ler: "Até quem é tolo pode tornar-se prudente, embora, ao nascer, pareça um filhote de asno selvagem". Assim sendo, embora aquele feto seja o de "um asno selvagem", e embora o presente imperial seja "tolo", há um caminho para a prudência, essa esperança está no sacrifício, pois não existe personagem bíblico mais sacrificado que Jó, o qual, apesar da sanha com que um acólito do demônio o priva de tudo o que ele obteve na vida, com perdas materiais e afetivas, com doenças e outras atrocidades, ao final, é recompensado por Deus. Sacrificar o sistema de produção, o favor, e outras mesquinhezes coloniais que persistem no presente em nome da verdadeira liberdade, é isso que parece reclamar a Meditação. E para tal, apresentam-se um pensamento, uma direção e um caminho na contracorrente da ideologia dominante, num embate contraideológico que só será superado pelo ímpeto abolicionista de Joaquim Nabuco, quatro décadas depois.

Estruturalmente, no segundo capítulo, após a epígrafe, aparecem novamente os pontos suspensivos. Desta vez, tudo indica que o recurso é para ocultar o procedimento que prepara o jovem para as visões, pois a parte II começa "E eu continuei, dizendo [...]", isto é, o narrador já está extático. A fórmula do estado de epifania fica no tinteiro do poeta. Nesse capítulo, principalmente, a presença dos opostos, isto é, a tensão entre os polos, que ganha vigor e volume, parece sugerir uma espécie de conciliação que, sem superação dialética, reúne a forma da verdade na própria estrutura dos coincidentia oppositorum, na seguinte fórmula: "Mas entre a severidade do velho e o devaneio do mancebo - está a verdade". Ou seja, é no par velho / mancebo, mais do que no par severidade / devaneio, que se articula a verdade. Na outra equação dessa fórmula está contido, também, o próprio afazer crítico de Gonçalves Dias: não se deve ser tão severo, mas tampouco há que delirar (devaneio). Os opostos reaparecem constantemente ao longo deste capítulo, como possível definição do ser humano, de sua natureza e da própria vida; condição que descreve de forma notável a ambiguidade do poeta: “Assim a vida também é uma alternativa de dor e prazer - de luz e trevas - de esperança e desesperação" (Gonçalves Dias, s. d., p.24), eis a fórmula condensada, levada à máxima consequência.

Há na Meditação uma crítica tipicamente romântica (a ambos os lados do Atlântico) que Gonçalves Dias desenvolve com originalidade. É a colocação em abismo da razão, a desconfiança de seu domínio. Mas, nesse caso, reformulada 
em termos não de inexatidão, mas de carência, pois a razão por si só não pode atingir a verdade, não serve como guia, é pouca luz, ou tanta que enceguece: "Insensatos! Pois a mesma razão não vos diz que ela é insuficiente para guiar-vos no caminho da vida?" (ibidem, p.30). A virtude teologal completaria o caminho, pois, na união desses opostos - razão e fé - residiria a verdade da meditação.

Essa fé passa da religião à política com resultados esperados. Pois dela nascem dois sentimentos modernos: a fé no progresso e o sentimento da nacionalidade. As nações são comparadas novamente com indivíduos e, dessa forma, afirma-se que "como existiram homens sem gênio; povos também existirão sem ele" (ibidem, p.31). O ancião adverte o jovem sobre os perigos da desídia por meio da inversão de um dos tópicos que mais força teria por esses anos: o determinismo geográfico, ou o fatalismo telúrico em sua forma romântica, com os postulados de Montesquieu, pois não seria o território (ou o clima, a geografia) ou a natureza os que incidem sobre os homens que ali habitam, mas é a natureza dos homens a que converte o entorno. Essa ideia é muito mais moderna e revolucionária do que parece para a época em que foi escrita. Por esses anos, por exemplo, do outro lado do Prata, Domingo Faustino Sarmiento no conhecido Facundo. Civilização e barbárie, argumentava que o deserto dos Pampas, ou seja, o território, era o responsável pela falta de laço social e pelo predomínio da barbárie na Argentina. Gonçalves Dias inverte a direção do determinismo geográfico, colocando em boca do ancião a fórmula da preguiça e da indolência dos povos "sem gênio". Então, a novidade está dada por duas motivações. A primeira, sempre em boca do ancião, é um chamado à ação, à busca do próprio em detrimento da cópia: "Se não chamais 'Progressista' ao homem que vai servilmente colocando os pés sobre as pegadas de outrem, como chamais grande ou progressista ao povo que só imita” (ibidem, p.32). Não pode haver progresso na imitação, na cópia, porque o original só surge com o que é próprio, ergo: o nacional. A segunda é a prodigalidade da natureza, que não é hostil e que, na verdade, ao longo da visão, é parte da grandeza e da originalidade do "grande império", sendo apenas o homem o culpado por não enxergar o futuro. De fato, natureza e nação também se justapõem na meditação do jovem. Justaposição que lhe outorga historicidade (do começo dos tempos) e destino grandioso (terra bendita) ao império. A crítica sempre recai sobre tudo o que se encontra debaixo da frondosidade e nobreza das matas seculares, isto é, recai sobre os homens.

Na última parte do capítulo II aparece um programa para levar adiante a nação e atingir o bem desejado: o progresso. Trata-se da governabilidade. Aqui, Gonçalves Dias esgrime seus conhecimentos etimológicos e trabalha em vários planos a mesma ideia, porque como metáfora do bom governo utiliza nada menos que a navegação, a nave para atravessar o oceano, e "Como es sabido, el origen de la palabra gobierno se ubica en la voz egea del griego kubernao, término en lo esencial propio del léxico marino y empleado para indicar el instrumento con el que se orienta la embarcación, el acto de manejarlo y guiar la nave" (Colombo, 2003, 
p.15). Trata-se, com efeito, do timão e da força-guia que o dirige, que lhe dá direção. Ao longo dessa última parte, os fragmentos vaticinam, na voz do ancião, as claves para o mencionado progresso, os ventos são favoráveis, avançar-se-á inexoravelmente, mas sem direção, sem timão, isto é, sem governo, corre-se o risco de andar em círculos e cair em ciclos repetitivos. Basta traçar o destino e depois: "fazei assim com o povo; dai-lhe ideias do útil e do justo, e ele irá caminho do progresso" (ibidem, p.35). O ancião agrega a força necessária para tal empresa: "Dai-lhe Deus por base de sua instrução, porque Deus é o caminho, a luz, e a verdade, e fora d'ele não há progresso" (ibidem, p.36).

A pergunta que subjaz a essas diretrizes é clara: quem deveria dar todas essas coisas ao povo? Pergunta que vem desembocar em outro turvo rio, que na época começava a ganhar presença. Gonçalves Dias se mostra, mais uma vez, adiantado aos problemas que suscitariam o surgimento das multidões e sua participação política. Porque se o sistema escravista fosse desmontado, se o povo fosse educado, fosse instruído, fosse cristianizado (e por esses anos, isso podia significar civilizado), isto é, se o povo fosse incorporado à vida pública, todos esses novos cidadãos ostentariam a "igualdade", mas sempre haveria alguém acima deles, em pirâmide, guiando-os, marcando o rumo, segurando firmemente o timão. $\mathrm{O}$ círculo vira triângulo. Embora no texto não apareça uma única menção à palavra "democracia", pois no regime imperial isso causaria estridências e rápidas suspeitas, fala-se modernamente dos problemas da igualdade: "Mas vós dissestes no vosso orgulho - O povo manda - o povo é soberano; e eu governo o povo. [...] Porque eu o intimido com a minha presença, e ele se curva diante de mim como um tigre diante do homem que o soube domar" (ibidem, p.37). A pantera e seu grito de liberdade é agora um tigre domado, sem correntes, mas curvado diante de o domador (timoneiro). Mas o ancião arremete com fúria contra essa "néscia utopia", pois a discórdia estará presente por culpa do passado escravista, assim, os perigos da igualdade são ameaças para os atuais senhores, e aqui o leitor da Meditação também poderia encontrar entrelinhas outra advertência (enquanto se anuncia o ciclo iterativo):

E os que julgavam dominá-lo por todo o tempo da sua vida, serão os primeiros ludibriados - escarnecidos - e martirizados, porque ele se lembrará que obedeceu passivamente, e ser-lhe-á grato saborear a vingança do escravo feito senhor! Ser-lhe-á doce a vingança e a crueldade, porque ambas são instintos da fera, e tal como a fera é o povo que despedaça a obediência qual o tigre aos varões da sua jaula! (ibidem, p.38)

Há uma moderação nessa visão da liberdade e nos possíveis usos da igualdade. Ao parecer, o povo é uma fera, e a vingança poderia fazer rodar cabeças, ecos da Grande Revolução. Contudo, em tom bíblico, a solução estará, novamente, em Deus: "porque o Senhor disse: 'E se algum de vós quiser dominar sobre os seus irmãos, tornar-se-á o último dentre eles' / 'E assim será por todo o sempre, porque a palavra do Senhor é eterna"” (ibidem, p.39). 
O ancião cala e o jovem-narrador toma a palavra. Segue-se um confronto, um contraponto de vozes em que o jovem anuncia a possibilidade de concreção do projeto, apesar desses males enumerados pelo ancião. É o momento central da Meditação, o eu romântico se afirma tenazmente, ${ }^{6}$ sem negar a contraparte, mas elevando o próprio lugar, colocando-se de forma magistral como criador, como indivíduo moderno: "Pois talvez que a verdade resulte da imaginação e da experiência - a imaginação, que é fogo e crê, e a experiência, que é gelo e duvida!" (ibidem, p.42). Eis o lugar reclamado por Gonçalves Dias. Não nega os opostos, de fato, combina-os, mais uma vez, como forma de conhecimento e verdade, porém à "voz da experiência" ele the imprime o "fogo da imaginação". Ou seja, reclama um lugar autônomo para os jovens, isto é, para si. ${ }^{7} \mathrm{E}$ dessa forma, Gonçalves Dias traz à tona antecipadamente um tópico que terá uma presença marcante na América Latina, principalmente a partir da publicação do Ariel de José Enrique Rodó, em 1900, é o tópico do juvenilismo, a importância do ser jovem, de representar o novo, o possível câmbio e esperada mudança, contra aquilo que está anquilosado e retrasado, o antiquado. A Nação jovem contra a anciã e degradante Colônia. Observe-se como Gonçalves Dias impõe a voz do jovem que, sem assumir o controle do timão, vem anunciar o rumo a seguir:

Ancião, tu enumeraste escrupulosamente os seus erros [do povo] e concluíste contigo: - o povo vanglorioso e impávido não pode durar muito.

Eu, porém, levantarei minha voz na tua presença e derramarei meu pensamento na tua alma, para que escutes a minha voz, e para que respondas ao meu pensamento. (ibidem, p.43, grifo nosso)

E o que essa voz da imaginação vem dizer à experiência? Pois bem, nada menos que o anúncio do surgimento da nacionalidade, uma coisa nova, moderna, algo que o velho não conhecia e cuja ignorância o tinha levado a profetizar: "Este povo acabará". A voz do jovem narrador, sempre sob os efeitos da meditação, assevera: "Mas o que tu não sabes é que esse povo tem uma força, que o ampara, e que o sustenta validamente / Que essa força é o seu centro de gravidade, e que o seu centro de gravidade - é o patriotismo". E para ter certeza de que não haverá diferença entre as classes, o jovem lembra ao ancião que essa força vem se ramificando "por todas as grandes divisões políticas - por todas as classes - e por todas as famílias" (ibidem, p.45). O velho não pode conhecer valor tão moderno, o amor à pátria. A pátria resiste e tolera os opostos, essa é a grande verdade anunciada pelo jovem, que em forma de aforismo, quase de máxima kantiana, encerra o seu discurso com a seguinte sentença: "um povo com consciência dos seus direitos não pode perecer". O ancião assente ao afirmar que nunca viu um povo no qual se ostente mais amor à pátria e à liberdade; contudo, com o tom monocórdio e sábio da voz da experiência, adverte sobre o fingimento de tais sentimentos.

O último capítulo, o terceiro, difere dos anteriores em alguns aspectos. Em primeiro lugar, não se abre com a linha de pontos, o efeito já foi desvendado 
pelo leitor. Em segundo lugar, só as partes I a V foram publicadas, o resto permaneceu inédito até a aparição das Obras póstumas. Por último, nesse capítulo vão surgindo novas vozes para dialogar com o par jovem/ancião. Trata-se de outros anciãos que formam um coral de vozes dissonantes. A imagem do coral se impõe, pois, embora os anciãos se manifestem um de cada vez, no conjunto parecem ter o papel da voz da consciência como era entendida no teatro grego clássico.

$\mathrm{Na}$ primeira parte desse último capítulo, encontra-se condensado todo o arsenal indianista que Gonçalves Dias desenvolverá depois no melhor de sua produção poética. O jovem vislumbra o povo guerreiro e começa a dotá-lo de virtudes: "E vi que uma geração numerosa e não corrompida cobria a extensão do vasto Império" (ibidem, p.52). Os índios não estão corrompidos, são belos guerreiros que suscitam uma comparação com o "ar tranquilo das estátuas gregas": beleza e atemporalidade; os índios são a génesis do Brasil pensado por Gonçalves Dias: "E o seu amor era - a independência, a sua esperança - a glória, a sua vida - o trabalho, e o seu pensamento forte e livre como as vagas do oceano" (ibidem, p.52-3). Evidentemente, essa declaração que coloca a vida do índio ligada ao trabalho é diametralmente oposta à imagem dada pelos viajantes europeus, e, vale mencionar, à imagem recolhida pelo Gonçalves Dias (2002) etnógrafo às margens do Amazonas. A degradação do homem americano e sua incapacidade fabril, assim como sua indolência eram moeda corrente do pensamento pretensamente científico ao longo dos séculos XVIII e XIX, principalmente a partir das teses degenerativas dos naturalistas De Pauw e Buffon (Gerbi, 1996). Na Meditação, há uma aberta oposição entre o índio, que parece calcado do bon sauvage de Rousseau, e os homens "que chamamos civilizados", colocando a ambos no mesmo lugar, ocupantes do mesmo "vasto Império". Imediatamente compreendemos o porquê da expressão "que chamamos", pois todos os valores da civilização esperados são sistematicamente negados. Trata-se de uma crítica violenta contra a conquista portuguesa, a colônia e as missões jesuíticas. Aqueles homens que "pregavam a igualdade tratando os indígenas como escravos" (ibidem, p.56) eram movidos pela avareza, pela cobiça, pelo ouro e não pelos altos valores da civilização e do cristianismo. A comparação é imediata, quase automática, porque os tempos se misturam na visão-meditação; então, aquela escravização e violência avarenta da conquista têm ecos no presente, nos corpos subjugados dos negros africanos; a violência é a mesma, a avareza continua sendo o fim buscado. A história se repete, há um ciclo iterativo, ergo: a nave ainda navega em círculos; embora o vento ideal, e supostamente benéfico, do progresso continue a soprar.

$\mathrm{Na}$ visão, o indianismo de Gonçalves Dias chega a ser mais direto e efetivo que nas poesias ao chamar de "primeiro Brasileiro que encontramos na História" a um "índio converso" (ibidem, p.58) morto nobremente; o Brasil já estava latente na languidez colonial. A guerra contra os índios foi movida pela cobiça, 
porém há uma imagem que devemos salientar: "E no chão que eles cavaram para o assento da cruz, encontraram uma veia de ouro, que os distraiu do seu trabalho" (ibidem). Observe-se a inversão que opera a Meditação: a conquista não foi movida pelo ouro, foi o ouro que mudou (distraiu) a direção da conquista e apartou os conquistadores do trabalho. A maldição de Deus para a nação conquistadora, os lusitanos, que tinham se pervertido, encerra a segunda parte do capítulo final. E só na IV parte os vencedores entendem que "é preciso gênio além de incomparável força bruta” para reverter os desígnios divinos. Quando os vencedores incorporam o gênio local imediatamente "uma voz sonora e retumbante partiu do Ipiranga e foi do mar aos Andes e do Prata às margens do Amazonas" (ibidem, p.62); dessa forma se narra a separação da metrópole. Portugal fica para trás, com sua força bruta; o gênio local anuncia a independência. Contudo, a corrente que atava o "povo nascente" a Portugal permanecia visível, havia "sinais dela, e ninguém tentava arrancá-la, porque era forte e bifurcada" (ibidem, p.64).

Quais seriam os sinais ainda visíveis dessa corrente? Quais os elos que ligavam o povo brasileiro com esse passado ominoso de avareza e violência? Pois bem, a Meditação responde: "E os homens que se haviam congregado para perfazerem a obra da redenção, dividiram-se depois da lide em massas poderosas, não segundo a diversidade das opiniões, porém segundo a variedade das cores" (ibidem, p.65). Gonçalves Dias fecha o círculo de forma magistral, leva o problema - que desenvolveu na visão histórica condenando a conquista lusitana e o mau uso da religião - da redenção até o presente, a separação em cores que nos remete ao começo do texto: os círculos concêntricos divididos pelas cores. E deixa retumbar todas as expressões que justificam a escravatura:

E os homens que costumam a raciocinar sobre as coisas, como elas são e não como devem ser levantaram-se e disseram:

Os homens de cor preta devem servir, porque eles estão acostumados à servidão de tempos mui remotos, e o costume é também lei.

E os filósofos disseram:

Os homens de cor preta devem servir, porque são os mais fracos, e é lei da natureza que o mais fraco sirva ao mais forte.

E os proprietários disseram:

Os homens de cor preta devem servir, porque são o melhor das nossas fortunas, e nós não havemos de as desbaratar. (ibidem, p.65-6)

A força do costume, a lei da natureza e a justificação da reificação do escravo com o estatuto da propriedade privada são todos os argumentos dos conservadores, dos que vêm as coisas como são "e não como devem ser". Visão que sustentará, anos depois, o Alencar das Cartas de Erasmo.

E, então, como devem ser as coisas? É a pergunta central e implícita da Meditação. E ainda: qual é o lugar que ocupam os outros nessa lógica maniqueísta? E, por último, quem são esses outros? Nas páginas mais densas, em termos 
políticos, lemos entrelinhas algumas respostas: "E os homens de raça indígena e os de cor mestiça disseram em voz alta: 'E nós que faremos?' / Qual será o nosso lugar entre os homens que são senhores, e os homens que são escravos?" (ibidem, p.66). Os outros são os mestiços, e é aqui onde devemos colocar Gonçalves Dias, além da identificação com o jovem narrador, pois sua condição no momento de escrever a Meditação era a desses outros. E o que se reclama nessas linhas é central para compreender o lugar buscado, a autonomia intelectual: "Os brancos governam - os negros servem - bem é que nós sejamos livres" (ibidem, p.67). Mas, que tipo de liberdade sugere para esse outros? Trata-se da liberdade de dizer, de criticar, desde um lugar autônomo. É a liberdade dos modernos, não já a liberdade para, dos antigos, como sugeria Benjamin Constant em $D a$ liberdade dos antigos comparada com a dos modernos (1818) (ver Bobbio, 2000, Cap.1). Por isso, embora pareça contraditório, luta-se por um lugar insólito: "Vivamos pois na indolência e na ociosidade, pois que não necessitamos trabalhar para viver" e linhas depois: "Deixar-nos-ão no ócio, porque precisarão de nós e porque a nossa ociosidade lhes será necessária" (Gonçalves Dias, s. d., p.67). Se o negócio é a escravidão, que divide a sociedade entre senhores e escravos, proprietários e propriedades, quem não participar do nec otium pode bem viver sem essas afrontas nessa afirmação do ócio: "E nós seremos felizes". Porém, o penúltimo fragmento dos publicados sugere um lugar fora do ócio e do negócio, pois "o governo esquecia que o ócio produz crimes" (ibidem, p.68).

As partes que permaneceram inéditas levantam algumas questões interessantes, mas não agregam nada em termos conceituais às ideais críticas da $\mathrm{Me}$ ditação. As vozes de quatro anciãos marcam erros, contradições ou sugerem problemáticas que deveriam levar-se em consideração no momento de aceitar as coisas, não como são, mas como devem (ou deveriam) ser. Há duas referências à monarquia que, seguramente, não poderiam ter passado sem produzir mal-estar no Rio de Janeiro. A primeira aparece no discurso do terceiro ancião: "Curemos de nós somente, porque a vida é breve - precário o nosso lugar - e instável a aura do povo e o favor do monarca" (ibidem, p.80); o favor (e a palavra não carrega nenhuma inocência) do monarca é instável, não se encaixa na lógica dos méritos e sim na da arbitrariedade. A segunda surge durante a intervenção do quarto e último ancião, que pergunta (e "todos repetiam"): "O Rei que faz?"; a resposta produz o riso de todos: "O Rei dorme!" (ibidem, p.84). Por último, após ser delineado o perigo do próximo levantamento, quando a rebelião se preanuncia ao longo da XI parte, Gonçalves Dias consegue a ablução pessoal, numa das passagens de maior denuncia, pois se inscreve no presente da enunciação:

$\mathrm{E}$ o ancião me disse:

A vossa política é mesquinha e vergonhosa, e milagroso é o homem que sai dela limpo de mãos e de consciência.

Os Delegados da Nação que não contam com o voto aturado e livre de povo, vendem-se impudicamente. (parte XII, p.87) 
Dessa forma, Gonçalves Dias prefigura a democracia e se sente suficientemente limpo de mãos e consciência, pois fez a sua parte, levantou a voz para falar a verdade ao poder.

A modo de conclusão desta leitura da Meditação e da natureza dos males da Nação no Brasil do Segundo Reinado, podemos dizer que nos tempos dos Saquaremas, quando ser conivente com o sistema escravista e com o favor imperial era a regra, de fato, quando o favor e o nepotismo eram normas de ascensão e, ainda, quando o próprio imperador, D. Pedro II, financiou a publicação de $O$ Guanabara, onde apareceu fragmentada a Meditação, Gonçalves Dias se coloca firmemente do lado do progresso e marca um rumo, sem anunciar o timoneiro, para sair desse estado de "política mesquinha" que o cercava: a escravidão. Deixando de lado aqui o meramente anedótico acerca do contrariado ou não que se sentiu o poeta com a outorga da condecoração da Ordem da Rosa.

Pela densidade teórica e pela qualidade literária, numa prosa poética que não perde em análise, a Meditação resulta um texto extraordinário, apesar de ter sido relegado pela crítica. Um ensaio denso, preciso e precioso à altura de "Nuestra América" do poeta cubano José Martí. Basta elencar alguns dos postulados da Meditação, ao menos os mais eloquentes, a saber: a importância da imaginação (da obra) para dizer a história e a realidade política; o contato com a divindade como momento central de qualquer progresso; e os métodos para atingir ambas as coisas, que neste caso estariam contemplados na "verdadeira ciência, [que] não se colhe dos livros: ela vem com a meditação". Motivos suficientes, sem mencionar a incidência evidente de sua poesia, para colocar Gonçalves Dias entre os intelectuais mais lúcidos dos Romantismos na América Latina toda. E dizemos "intelectual" e não apenas poeta sabendo que tal apelativo poderia ser motejado de anacrônico, pois ainda Émile Zola não tinha acusado ao mesmíssimo presidente da república francesa para defender o injuriado Dreyfus. Mas, valemo-nos do termo com a convicção de que esse trabalho autônomo da crítica ao poder corresponde modernamente ao intelectual, e Gonçalves Dias o representou de forma eloquente. Como escreveu Edward Said (2005, p.99) (discurso que desejamos alinhar com o Gonçalves Dias da Meditação):

Minha questão é se, para o intelectual contemporâneo, vivendo numa época já confusa pelo desaparecimento do que parecem ter sido normas morais objetivas e autoridade sensível, é aceitável apoiar simplesmente, ou mesmo cegamente, o comportamento de seu próprio país e fechar os olhos aos seus crimes, ou dizer com bastante negligência: "Penso que todos fazem isso, e é assim que o mundo funciona". Ao contrário, o que devemos ser capazes de dizer é que os intelectuais não são profissionais desnaturados pela subserviência a um poder cheio de falhas, mas - repetindo - são intelectuais com uma posição alternativa e mais integra, que lhes permite, de fato, falar a verdade ao poder.

O poeta, o etnógrafo, o ensaísta, enfim, o intelectual Gonçalves Dias não fechou os olhos aos crimes cometidos no Brasil, e se o fez, momentaneamente, foi apenas para tramar uma visão fragmentária que na sinédoque prefigura a to- 
talidade. Ao agir assim, mesmo num texto completamente periférico dentre os consagrados pela crítica do movimento romântico local, Gonçalves Dias conseguiu confrontar, embora mantendo a ambiguidade do olhar, o maior horror que o Brasil monárquico não consegue dissimular: a ominosa realidade do cativeiro dos escravos negros. A Nação, a jovem nação brasileira, contudo, é apresentada com um destino e um futuro de esplendor. Porém, esse devir se materializa na visão profética, só se as críticas forem atendidas. Críticas certeiras e bem explicitadas, nessa forma ensaística que permite a soltura do estilo e a clareza de ideias, numa prosa sempre próxima do poético. Dessa forma, contra a corrente, ${ }^{8}$ no lado oposto ao de Alencar e ao da ampla maioria da elite letrada, ao menos no final da década de 1840 (quando o texto é escrito) e no começo da década de 1850 (quando o texto é publicado), Gonçalves Dias é pioneiro ao gerar um espaço autônomo que lhe permite sair da lógica do favor, e dessa forma, com a voz clara, mas com as dúvidas sobre sua periculosidade, falar a verdade ao poder.

Notas

1 Este artigo, originalmente, é parte do capítulo 3 da tese de doutorado Naturaleza, Nación y tensión en los romanticismos argentino y brasileño, defendida na USP em 6 de agosto de 2015. Contudo, algumas alterações foram realizadas para esta publicação.

$2 \mathrm{O}$ capítulo 3 está subdividido em treze partes com números romanos. As partes I a V foram publicadas na revista $O$ Guanabara junto com o resto do texto. As partes VI a XIII foram recolhidas por Antônio Henriques Leal nas Obras póstumas que aqui utilizamos.

3 Todas as citações pertencem a esta edição. Adaptamos a grafia original às normas vigentes do português.

4 Os dados para elaborar o quadro foram tomados de: Jancsó (2000).

$5 \mathrm{O}$ ancião fala dos egípcios, dos árabes e dos gregos, da monumentalidade de obras como as pirâmides e conclui que tudo aquilo foi possível "porque eles eram livres nos atos e nos pensamentos", sendo que, como é sabido, todas essas civilizações se serviram da escravatura para realizar tanto esses trabalhos como os mais domésticos.

6 Para os românticos, conhecer seu objetivo verdadeiro "não é conhecer a verdade tal como concebida pelo pensamento iluminista, segundo o qual primeiro descobre-se a verdade, depois aplica-se; ao invés disso, sua ação em si expressa - é una com - suas convicções. Moral e política não são um conjunto de proposições: são ação, autodedicação a objetivos tornados concretos", repara Isaiah Berlin (1999, p.254).

7 Até o próprio ancião acaba aceitando o valor da juventude, pois seus dias já "declinaram como a sombra", mas "não assim o mancebo! Seus olhos são como um prisma, seu coração como uma fogueira, e o seu gênio impetuoso como a torrente" (ibidem, p.23).

8 No único texto quase inteiramente dedicado à Meditação que encontramos, Wilton José Marques (2010) coloca Gonçalves Dias, já do título, nesse revés de trama, como o que pode dizer aquilo que os outros preferem calar, apesar da evidência. 
Referências

ALVES CUNHA, C. Introdução. In: GONÇALVES DIAS, A. Cantos. São Paulo: Martins Fontes, 2001.

BERLIN, I. O sentido da realidade. Estudos das ideias e de sua história. Rio de Janeiro: Civilização Brasileira, 1999.

BOBBIO, N. Liberalismo y democracia. México: Fondo de Cultura Económica, 2000.

BOSI, A. Dialética da colonização. São Paulo: Cia. das Letras, 1992.

. História concisa da Literatura Brasileira. São Paulo: Cultrix, 2006.

As ideologias e o seu lugar. In: _. Entre a literatura e a história. São Paulo:

Editora 34, 2013.

CANDIDO, A. Formação da literatura brasileira. Belo Horizonte: Itatiaia, 2000.

CARVALHO, M. de. A construção da ordem. A elite política imperial. Rio de Janeiro: Civilização Brasileira, 2008.

COLOMBO, P. Gobierno. Léxico político. Buenos Aires: Nueva Visión, 2003.

GERBI, A. O novo mundo: História de uma polêmica (1750 - 1900). São Paulo: Cia. das Letras, 1996.

GONÇALVES DIAS, A. Correspondência Ativa. Anais da Biblioteca Nacional, Rio de Janeiro, v.84, 1964.

- Poesia e prosa completas. Rio de Janeiro: Nova Aguilar, 1998.

. Gonçalves Dias na Amazônia. Relatórios e Diários de Viagem ao Rio Negro.

(Introdução de Josué Montello). Rio de Janeiro: Academia Brasileira de Letras, 2002.

Meditação. In:

Obras posthumas de A. Gonçalves Dias. Rio de Janeiro:

Garnier, s. d. (Precedidas de uma notícia da sua vida e obra pelo Dr. Antônio Henriques Leal).

GUINSBURG, J. (Org.) O romantismo. São Paulo: Perspectiva, 1978.

JANCSÓ, I. (Dir.) Cronologia de História do Brasil Monárquico (1808 - 1889). São Paulo: Humanitas; Departamento de História - FFLCH - USP, 2000.

MARQUES, W. J. Gonçalves Dias e a burocracia imperial: favores e afrontas. In: MOTTA OlIVEIRA, P. (Org.) Figurações do oitocentos. São Paulo: Ateliê, 2008.

Gonçalves Dias: o poeta na contramão. Literatura e escravidão no romantismo

Brasileiro. São Carlos: EduFSCar, 2010.

MORITZ SCHWARCZ, L. (Dir.) História do Brasil Nação: 1808-2010. Rio de Janeiro: Objetiva, 2013. v.2: “A construção nacional (1830-1889)" (coord. José Murilo de Carvalho).

PEREIRA, L. M. A vida de Gonçalves Dias. Rio de Janeiro: José Olympio, 1952.

SAID, E. Falar a verdade ao poder. In: __. Representações do intelectual. As conferências Reith de 1993. São Paulo: Cia. das Letras, 2005.

SARMIENTO, D. F. Viajes por Europa, África y América. 1845-1847. Buenos Aires: Luz del Día, 1949.

SPIX \& MARTIUS. Viagem pelo Brasil. São Paulo: Melhoramentos, s. d. v.I, Libro 2. 
RESUMO - Este artigo tem o intuito de realizar uma leitura crítica da obra em prosa poética Meditação, do poeta maranhense Gonçalves Dias. Dita obra, publicada fragmentariamente na revista $O$ Guanabara no começo da década de 1850 , foi relegada pela crítica especializada, concentrada, geralmente, na produção poética de Gonçalves Dias e, em menor medida, na produção etnográfica. Trata-se de um texto no qual o autor exerce a crítica de forma eloquente, num movimento contraideológico notável para a época.

PALAVRAS-CHAVE: Gonçalves Dias, Romantismo brasileiro, Escravidão, Intelectual, Brasil Império.

ABSTRACT - This article makes a critical reading of Meditação, the work in poetic prose by Maranhão-born poet Gonçalves Dias, published piecemeal in the magazine $O$ Guanabara in the early 1850s. Meditação was relegated by the critics, who concentrated on Gonçalves Dias' poetic production and, to a lesser extent, on his ethnographic production. It is a text in which the author is eloquently critical, in a counter-ideological movement remarkable at the time.

KErWORDS: Gonçalves Dias, Brazilian Romanticism, Slavery, Intellectual, Brazil Empire.

Diego A. Molina é licenciado em Letras Modernas (com especialização em Literatura Argentina e Latino-americana) pela Universidade de Buenos Aires (2007), mestre em Literatura Brasileira e doutor em Literatura Hispano-americana pela USP. Atualmente realiza pós-doutorado em Literatura Brasileira na USP. É pesquisador no grupo de Cultura e Literatura do Instituto de Estudos Avançados da USP. E no grupo de pesquisa da "Historia Comparada de las literaturas argentina y brasileña" da Universidade de Buenos Aires. @-diegomolina@usp.br

Recebido em 26.10.2015 e aceito em 21.12.2015.

${ }^{\text {I }}$ Faculdade de Filosofia, Letras e Ciências Humanas, Universidade de São Paulo, São Paulo/São Paulo, Brasil. 